\title{
Incorporation of $\mathrm{Y}_{2} \mathrm{O}_{3}$ Particles into 410L Stainless Steel by a Powder Metallurgy Route
}

\author{
A. Zeybek, S. Pirfo Barroso, K.B. Chong, L. Edwards, and M.E. Fitzpatrick
}

\author{
(Submitted September 10, 2013; in revised form March 21, 2014; published online April 11, 2014)
}

\begin{abstract}
Addition of yttria to steels has been proposed for the fabrication of oxide-dispersion-strengthened materials for nuclear power applications. We have investigated materials prepared from $12 \mathrm{Cr}$ martensitic stainless steel, AISI 410L, produced by powder metallurgy. Materials were produced with and without yttria addition, and two different sizes of yttria were used, $0.9 \mu \mathrm{m}$ and $50 \mathrm{~nm}$. Tensile and mini-creep tests were performed to determine mechanical properties. Optical microscopy, SEM, TEM, and EDX analysis were used to investigate the microstructures and deformation mechanisms and to obtain information about nonmetallic inclusion particles. $\mathrm{SiO}_{2}, \mathrm{MnS}$, and $\mathrm{Y}_{2} \mathrm{Si}_{2} \mathrm{O}_{7}$ inclusion particles were observed. $\mathrm{An} \mathrm{SiO}_{2}$ and $\mathrm{Y}_{2} \mathrm{O}_{3}$ interaction was seen to have occurred during the ball milling, which impaired the final mechanical properties. Small-angle neutron scattering experiments showed that the matrix chemistry prevented effective dissolution of the yttria.
\end{abstract}

Keywords advanced characterization, creep and stress rupture, mechanical, powder metallurgy

\section{Introduction}

The current most common commercialized nuclear fission reactors work at a temperature range of $250-300{ }^{\circ} \mathrm{C}$, a pressure range of 7-15 $\mathrm{MPa}$, and displacement per atom (dpa) in core structural components of 10-25. Future innovative nuclear systems and technologies have designs much more demanding on material performance. Some so-called "Generation IV" designs have operating requirements up to $1100{ }^{\circ} \mathrm{C}, 24 \mathrm{MPa}$, and dpa up to 150 .

Efforts to develop new Fe-Cr-Mo-type heat-resistant steels were initiated for steam generators in the early 1970s. During the development of high-chromium ( 9 to $12 \%$ ) steels for hightemperature application, the use of stainless steel for nuclear applications was demonstrated. This included attempts to replace Mo with $\mathrm{W}$ to reduce the radio-activation of the material (Ref 1). Since then, much experience has been gained

A. Zeybek, Materials Engineering, The Open University, Walton Hall, Milton Keynes MK7 6AA, UK; and Defence Industries Research and Development Institute (TÜBITAK-SAGE), 1606261 Mamak, Ankara, Turkey; S. Pirfo Barroso, Materials Engineering, The Open University, Walton Hall, Milton Keynes MK7 6AA, UK; K.B. Chong, Materials Engineering, The Open University, Walton Hall, Milton Keynes MK7 6AA, UK; and High Performance Computing Centre, University Malaysia of Computer Science \& Engineering, Persiaran APEC, Cyberjaya Flagship Zone, 63000 Cyberjaya, Selangor Darul Ehsan, Malaysia; L. Edwards, Australian Nuclear Science \& Technology Organisation, Locked Bag 2001, Kirrawee, Sydney, NSW 2234, Australia; and M.E. Fitzpatrick, Materials Engineering, The Open University, Walton Hall, Milton Keynes MK7 6AA, UK; and Faculty of Engineering and Computing, Coventry University, 3 Gulson Road, Coventry CV1 2JH, UK. Contact e-mail: michael.fitzpatrick@coventry. ac.uk. with components fabricated with high-Cr martensitic steel (Ref 2). Austenitic stainless steels are not preferred for advanced nuclear reactor applications because of high swelling rates and high thermal stresses caused by low thermal conductivity and high thermal expansion coefficient.

Structural materials for future nuclear applications have to be stable at elevated temperatures and have good resistance to irradiation. This resulted in focussing structural materials research on ferritic-martensitic (F/M) steels. Presently, F/M steels are the primary candidate for components of advanced reactor systems such as fuel cladding and duct materials. Precipitates are a major source of strength in $\mathrm{F} / \mathrm{M}$ steels. Processing procedures that decrease the size of precipitates and increase their number density could enhance mechanical properties. This is akin to the so-called oxide-dispersion-strengthened (ODS) steels, where particles are dispersed into the steel matrix resulting in an increase in strength at higher temperatures (higher creep resistance). ODS steels have been visualized as an alternative to increase the creep resistance of the ferritic, martensitic, or F/M steels (Ref 3). Powder metallurgy is the most commonly used method of producing ODS steels.

The dispersion particles are generally $\mathrm{Ti}_{2} \mathrm{O}_{3}$ and/or $\mathrm{Y}_{2} \mathrm{O}_{3}$. The first ODS steels were of high chromium (12 up to $20 \% \mathrm{Cr}$ ). Attempts to solve the anisotropy problems caused by grain structure and a strong deformation texture resulted in the use of 9-11\% Cr, 2-3\% W and by the austenite-to-martensite transformation (through cooling from the austenization treatment temperature). The $\mathrm{Cr}$ content is also optimized to achieve higher toughness and lower ductile-to-brittle transition temperatures. The resulting steels have outstanding tensile properties and reduced anisotropy, but the creep-rupture properties are reduced compared to the high-chromium ODS steels (Ref 3, 4).

Following initial work on ODS as potential materials for nuclear applications in the 1990s, there has recently been significant interest in the fabrication of fuel cladding based on ODS materials, as a replacement for zirconium alloys in pressurized water reactors, and also for sodium-cooled designs (Ref 5). For nuclear applications, steels chosen for base alloy 
are reduced-activation composition steels, so that mechanical properties at high temperatures such as resistance to creep and recrystallization are improved, without loss of the advantages of the ferritic or martensitic microstructures, especially the resistance to void swelling (Ref 6-8). The large interface area associated with a small volume $(0.25 \%)$ of yttria addition provides "sinks" for radiation damage and implanted ions in a reactor core (Ref 9). The complex, ultrafine-grained microstructure consists of nanoclusters that are highly tolerant to high dose irradiation at elevated temperatures (Ref 10).

The chemistry of the base alloy can have an effect on the stability and dissolution of the ODS particles during processing. Titanium additions to the alloy have been found to promote yttria dissolution during processing and stabilize the particle size during subsequent heat treatment and forming (Ref 11).

The ODS particles effectively anchor dislocations, thus enhancing creep resistance, manifested as a decrease in creep ductility and an increase in creep-rupture life (Ref 12). However, studies trying to establish the upper operating temperature limit for these steels (Ref 13-15) are finding that the creep behavior is very sensitive to composition and microstructure. The fatigue properties have also been found to depend on the processing route and final microstructure (Ref 16).

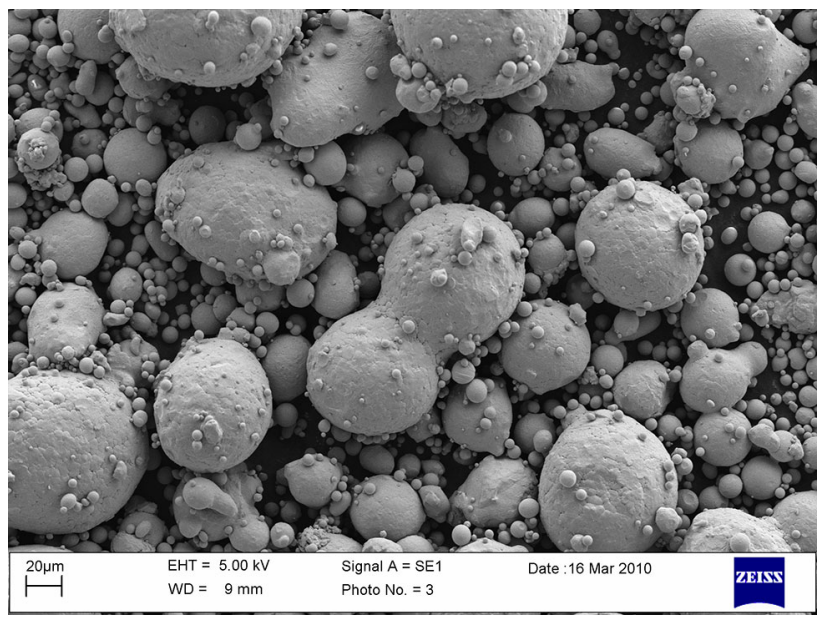

Fig. 1 Scanning electron microscope image of gas-atomized 410L powder

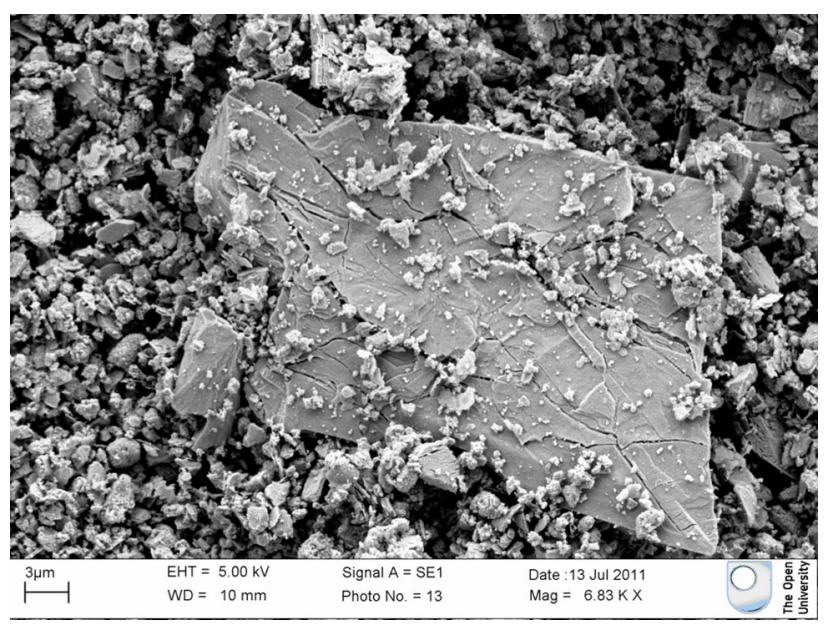

Fig. 2 SEM image of yttria powders showing a large particle. The nominal particle size was $0.9 \mu \mathrm{m}$
Small-angle neutron scattering (SANS) has been found to be a valuable technique for the study of ODS steels, as it can reveal the distribution of the particles at the nanometre scale (Ref 17). Conventional neutron and x-ray diffraction methods
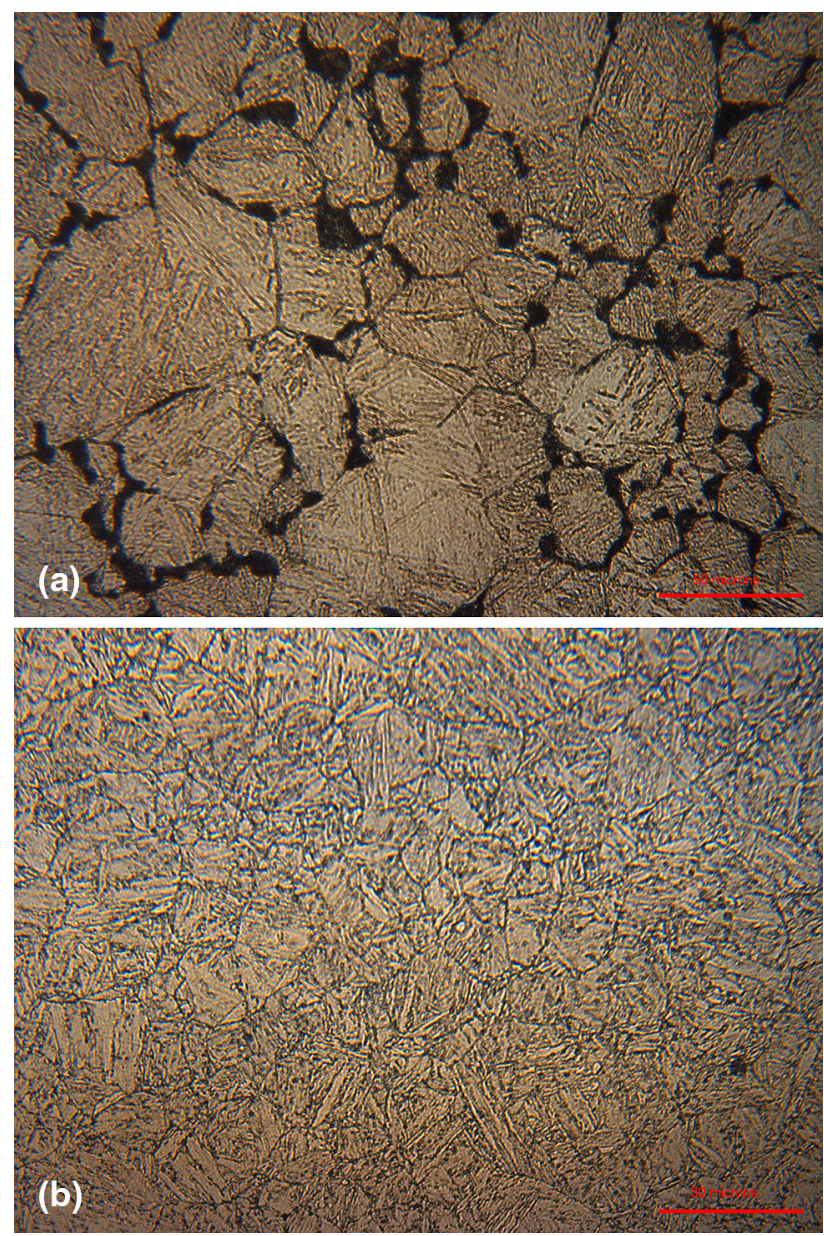

Fig. $3410 \mathrm{~L}$ as-received material without MA etched in Villela's reagent (a) without heat treatment (b) After heat treatment

Table 1 Tensile test results at room temperature

\begin{tabular}{lccc}
\hline $\begin{array}{l}\text { Material } \\
\text { 410L base }\end{array}$ & $\begin{array}{c}\text { Yield strength, } \\
\text { MPa }\end{array}$ & $\begin{array}{c}\text { Ultimate tensile } \\
\text { strength, MPa }\end{array}$ & $\begin{array}{c}\text { Fracture } \\
\text { strain, \% }\end{array}$ \\
\hline $\mathrm{HIP}$ only & 675 & 814 & 18 \\
$\mathrm{MA}$ and $\mathrm{HIP}$ & 677 & 842 & 15 \\
ODS-0.9- $\mu \mathrm{m} \mathrm{Y}_{2} \mathrm{O}_{3}$ & 695 & 860 & 12 \\
ODS-50-nm $\mathrm{Y}_{2} \mathrm{O}_{3}$ & 690 & 845 & 10.5 \\
\hline
\end{tabular}

Table. 2 Tensile test results at $625^{\circ} \mathrm{C}$

\begin{tabular}{|c|c|c|c|}
\hline $\begin{array}{l}\text { Material } \\
\text { 410L base }\end{array}$ & $\begin{array}{c}\text { Yield } \\
\text { strength, MPa }\end{array}$ & $\begin{array}{c}\text { Ultimate } \\
\text { tensile } \\
\text { strength, MPa }\end{array}$ & $\begin{array}{l}\text { Fracture } \\
\text { strain, \% }\end{array}$ \\
\hline HIP without MA & 270 & 283 & 16 \\
\hline MA and HIP & 266 & 289 & 9 \\
\hline ODS-0.9- $\mu \mathrm{m} \mathrm{Y}_{2} \mathrm{O}_{3}$ & 275 & 292 & 10 \\
\hline ODS-50-nm $\mathrm{Y}_{2} \mathrm{O}_{3}$ & 273 & 293 & 5 \\
\hline
\end{tabular}


Table 3 Creep results

\begin{tabular}{|c|c|c|c|c|c|}
\hline Material & Temp, ${ }^{\circ} \mathrm{C}$ & Stress, MPa & Rupture time, $h$ & Elongation, $\%$ & Strain rate, $10^{-4} \times \mathrm{h}^{-1}$ \\
\hline \multirow[t]{3}{*}{410 HIP } & 625 & 150 & 20 & 26.0 & 44.44 \\
\hline & 625 & 100 & 205 & 21.5 & 5.00 \\
\hline & 625 & 75 & 679 & 16.4 & 1.36 \\
\hline \multirow[t]{3}{*}{$410 \mathrm{MA}$} & 625 & 150 & 11 & 30.2 & 118.42 \\
\hline & 625 & 100 & 117 & 23.7 & 9.37 \\
\hline & 625 & 75 & 242 & 22.8 & 4.44 \\
\hline \multirow[t]{3}{*}{ ODS $0.9 \mu \mathrm{m}$} & 625 & 150 & 7.3 & 24.2 & 142.85 \\
\hline & 625 & 100 & 61 & 17.3 & 14.28 \\
\hline & 625 & 75 & 216 & 9.5 & 3.00 \\
\hline \multirow[t]{3}{*}{ ODS $50 \mathrm{~nm}$} & 625 & 150 & 2.7 & 8.0 & 230.76 \\
\hline & 625 & 100 & 27 & 7.4 & 17.14 \\
\hline & 625 & 75 & 108 & 6.9 & 4.44 \\
\hline
\end{tabular}

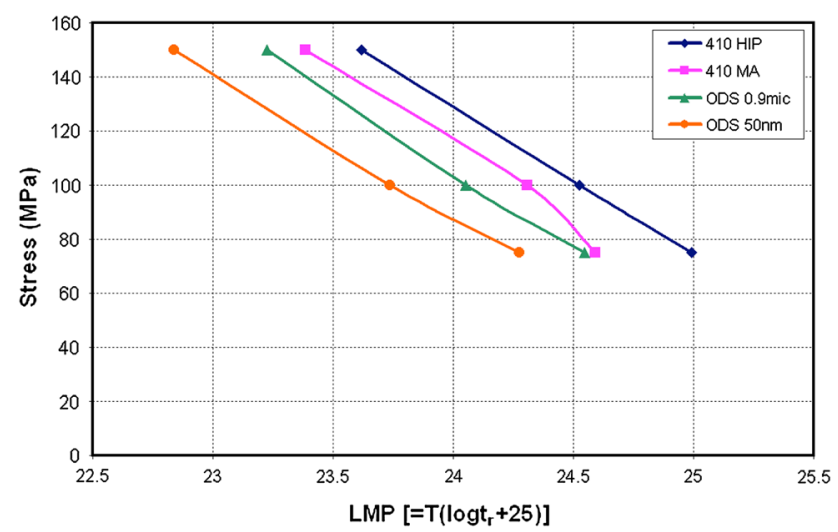

Fig. 4 Larsson Miller Parameter graph for the materials from the mini-creep tests

can also be valuable in looking at the evolution of phases and dissolution in ODS materials (Ref 18, 19).

This work presents the results of a study on the powder metallurgy processing of an ODS 410L alloy steel. The microstructural evolution and mechanical properties were examined and measured. SANS was used to examine the dispersion and inclusion particles.

\section{Experimental Details}

The base material was AISI 410L powder with nominal composition of $11.5-13$ wt.\% Cr, $\max 1$ wt.\% Si, $\max 1$ wt.\% Mn, max 0.5 wt. $\% \mathrm{~S}$, and $\max 0.5$ wt. $\%$ P. Two different particle sizes of yttria were used for incorporation into the material: $50 \mathrm{~nm}$ and $0.9 \mu \mathrm{m}$. These sizes were selected to provide a comparison with a particle size that is effectively comprised of single crystallites and can be incorporated into the matrix by dissolution $(50 \mathrm{~nm})$, and a larger size which offers greater scope for particle fracture during the mechanical milling process.

Scanning electron microscope (SEM) observations on the atomized $410 \mathrm{~L}$ powder (Fig. 1) show particle sizes smaller than $100 \mu \mathrm{m}$, which is suitable for subsequent powder metallurgy operations. The morphology of the alloyed powder shows spherical particles. Some larger metal powder particles have many small "satellites" stuck to them, which ideally should be eliminated for good packing and flow attributes (Ref 20).

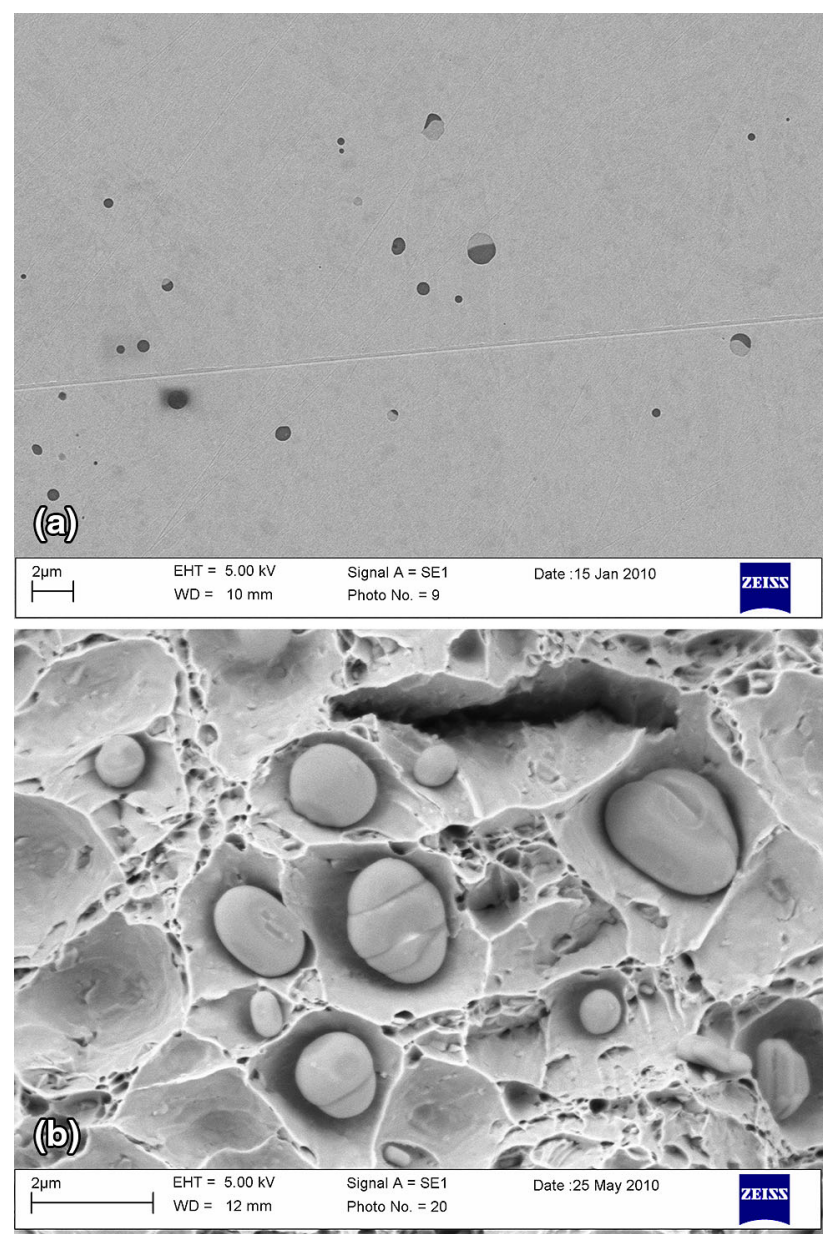

Fig. 5 Particle clusters in the material: (a) in 410L HIP material; (b) Fracture surface SEM images of ODS with $0.9 \mu \mathrm{m} \mathrm{Y}_{2} \mathrm{O}_{3}$

SEM observations on the yttria powders showed particles much larger than expected, with some particles up to $30 \mu \mathrm{m}$ in size, with composition of pure yttrium rather than yttria. Both yttria powders, nominally of $0.9 \mu \mathrm{m}$ and $50 \mathrm{~nm}$ in size, show these large particles, with an example shown in Fig. 2 for the $0.9-\mu \mathrm{m}$ powder.

Materials were fabricated by Aerospace Metal Composites Ltd, Farnborough, by a mechanical alloying (MA), powder metallurgy route. The ODS material was fabricated by mechanical milling $0.25 \mathrm{wt} . \% \mathrm{Y}_{2} \mathrm{O}_{3}$ with the alloy powders under inert 


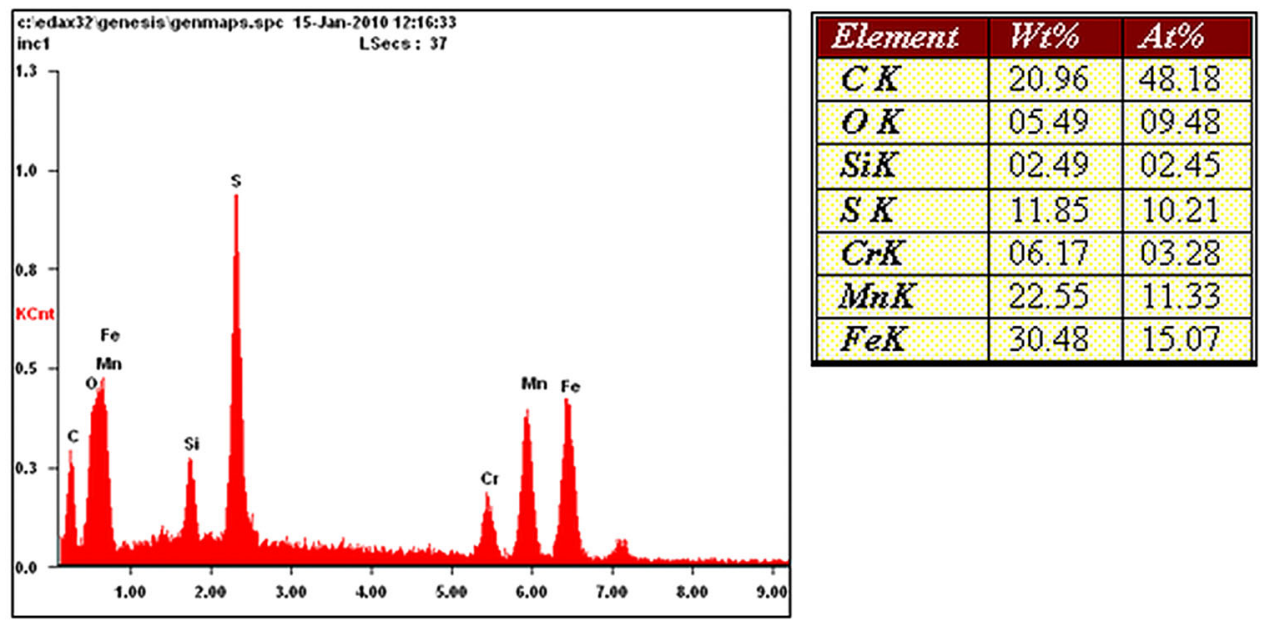

(a)

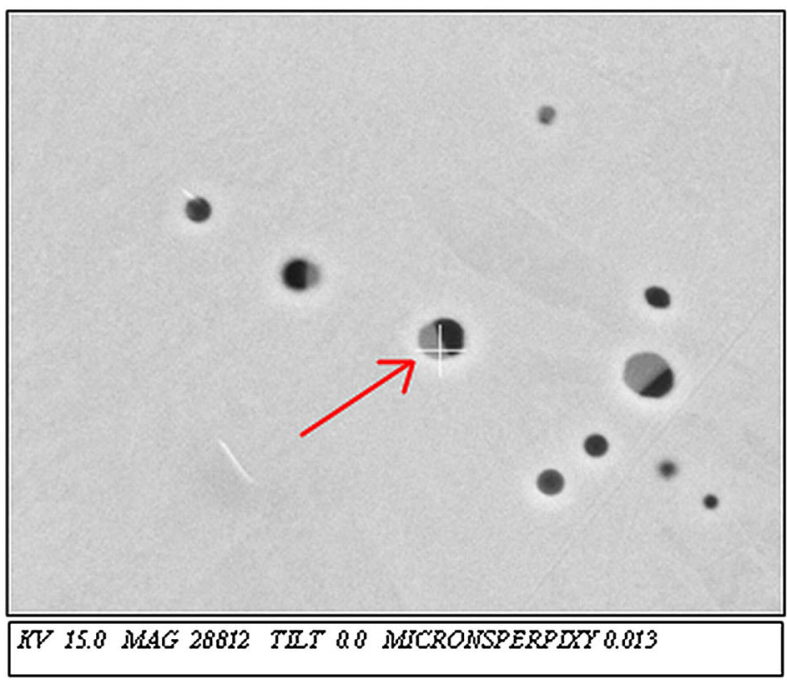

Fig. 6 EDX results from two sides of a compound particle, showing (a) probable $\mathrm{MnS}$ on one side and (b) $\mathrm{SiO}_{2}$ on the other

argon atmosphere. Two different ODS variants were produced with $\mathrm{Y}_{2} \mathrm{O}_{3}$ particles of $0.9 \mu \mathrm{m}$ and $50 \mathrm{~nm}$ sizes. After milling, the powders were canned and degassed. After degassing, the can was sealed. Finally, hot isostatic pressing (HIPping) was performed at a temperature of $1120{ }^{\circ} \mathrm{C}$. Materials were also produced without oxide reinforcement, and one batch was prepared by simple consolidation of the 410 powder without the MA stage.

Heat treatment was performed on the final billets to achieve a tempered martensitic structure and remove features such as residual ferrites at grain boundaries arising due to the slow cooling rate (furnace cooling) after HIPping. The microstructures of as-received unreinforced 410 material without MA, before and after heat treatment, are shown in Fig. 3.

The heat treatment was austenitizing at $1000^{\circ} \mathrm{C}$ for $30 \mathrm{~min}$ followed by oil quenching to achieve a fully martensitic microstructure and then tempering at $650{ }^{\circ} \mathrm{C}$ for $2 \mathrm{~h}$ and furnace cooling. The heat treatment was performed under ambient atmosphere. In Fig. 3b, it can be seen that a fully tempered martensitic microstructure was achieved by the heat treatment. No residual ferrite was observed.

Cylindrical tensile test specimens were extracted from the longitudinal direction of the HIP billets (though it must be noted that no direction-dependence in the properties would be expected). The tensile test specimens were $6.25 \mathrm{~mm}$ in diameter and $25 \mathrm{~mm}$ in gage length. The tensile samples were tested to failure at room temperature and at $625{ }^{\circ} \mathrm{C}$ at an extension rate of $0.01 \mathrm{~mm} / \mathrm{s}$.

Creep tests were carried out by applying a fixed tensile load at various temperatures. The "mini-creep" samples used had dimensions of $10 \mathrm{~mm}$ in gage length and $2 \mathrm{~mm}$ in diameter. Mini-creep tests were conducted at the Australian Nuclear Science and Technology Organisation (ANSTO) facilities. All tests were conducted in vacuum at $625{ }^{\circ} \mathrm{C}$ under loads of 75 , 100 , and $150 \mathrm{MPa}$.

The SANS experiment was performed on the KWS-1 instrument of JCNS at FRM-II, Munich. A magnetic field was applied at 0.4 and $1.2 \mathrm{~T}$ with a neutron wavelength of $7 \AA$. Rectangular samples were manufactured with dimension of $20 \times 20 \mathrm{~mm}^{2}$ with thickness of $2 \mathrm{~mm}$. This thickness was chosen as higher thickness can cause multiple scattering (Ref 21). The instrument has an upper length scale limitation of $400 \mathrm{~nm}$. A polydispersed spherical Schultz distribution/model was used for data analysis and fittings.

\section{Results}

\subsection{Mechanical Properties}

A summary of the tensile test results at room temperature is shown in Table 1. Yield strength values are around 


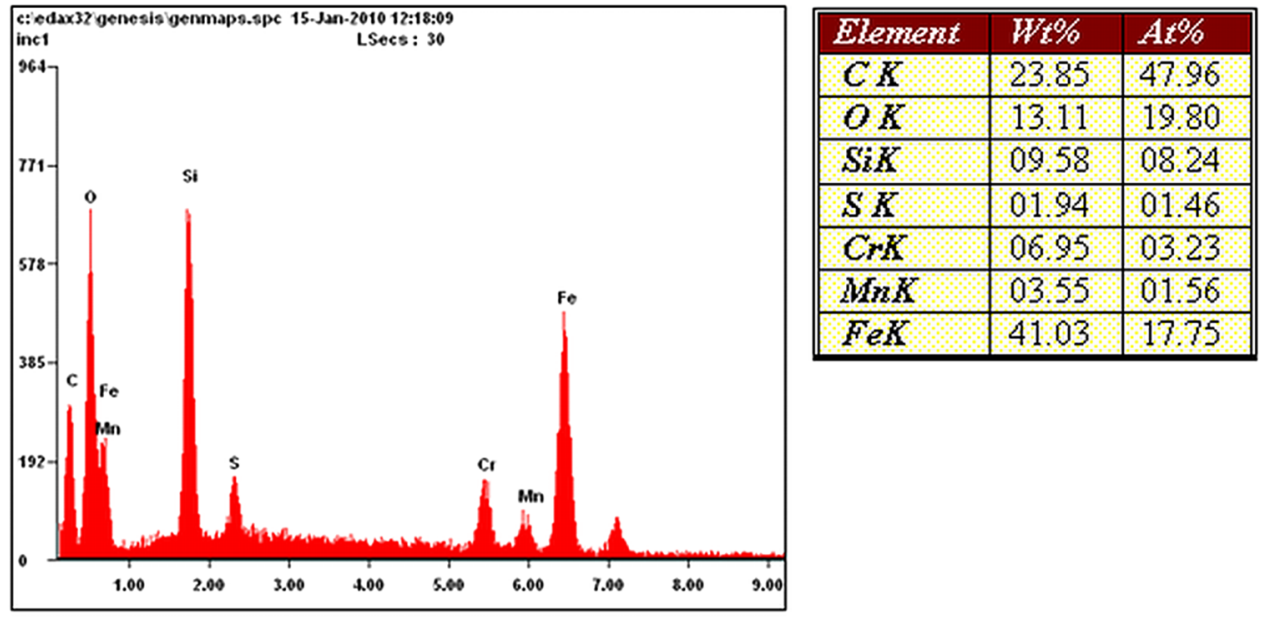

(b)

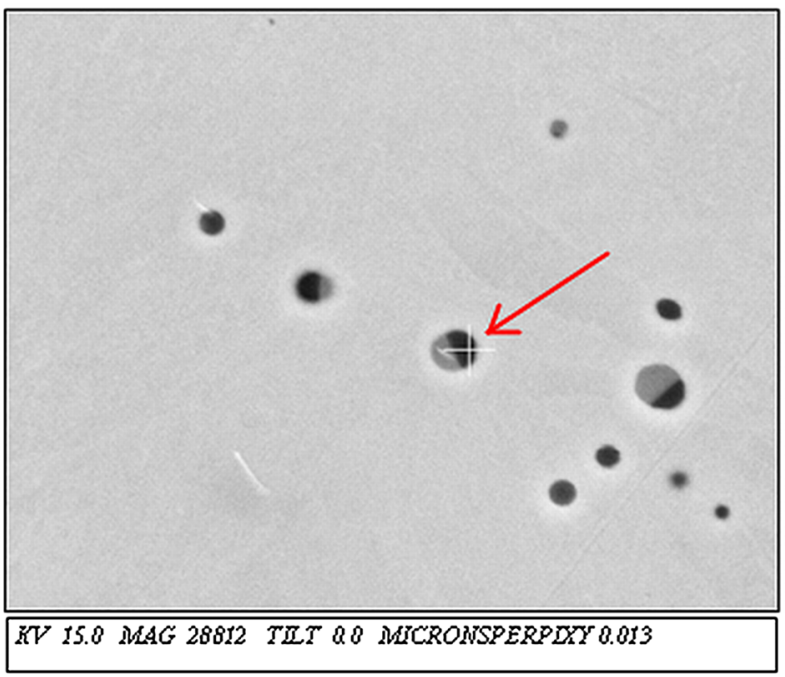

Fig. 6 continued

670-690 MPa, and ultimate tensile strength (UTS) values are around 815-860 MPa. Typical mechanical properties of 410L produced by conventional methods (cast and machined) and submitted to similar heat treatments show strengths slightly lower than observed for the material presented here. The conventionally produced steel shows yield and ultimate strengths of about 589 and $767 \mathrm{MPa}$, respectively (data from the 410 Specification Sheet, Sandmeyer Steel Company).

The material that was mechanically alloyed before HIPping showed a small increase in UTS, from 814 to $842 \mathrm{MPa}$. Thus, it can be concluded that the MA has a small effect on the room temperature strength of the steel, which is in agreement with previous work by Morakotjinda et al. (Ref 3) and Brytan et al. (Ref 22).

The addition of $\mathrm{Y}_{2} \mathrm{O}_{3}$ did not impact significantly on the strength of the material at room temperature. The highest mechanical properties are observed for the ODS-0.9- $\mu \mathrm{m}$ material with yield strength of $695 \mathrm{MPa}$ and UTS of $860 \mathrm{MPa}$.

Conventional 410L has strain-to-failure of the order of $18 \%$. The 410 HIP and 410 MA + HIP samples have fracture elongation values of 18 and $15 \%$, respectively. It is well known that MA has a negative effect on ductility (Ref 23).

As expected, the yttria particles have a negative effect on fracture strain due to hindering dislocation motion. Thus, the ODS materials are less ductile than the non-ODS versions. The
ODS-0.9- $\mu \mathrm{m}$ and 50-nm samples have fracture elongations of 12 and $10.5 \%$, respectively. Previous work has found different trends depending on the system studied.

High-temperature tensile tests on the samples were conducted at $625^{\circ} \mathrm{C}$, and the results are shown in Table 2. Yield strength values are around $270 \mathrm{MPa}$, and UTS is around $285 \mathrm{MPa}$. As expected, yield strength and UTS values are lower than room temperature values which were around 680 and $840 \mathrm{MPa}$ for yield and tensile strengths, respectively. Note that the low ductility seen for the 50-nm ODS material in this case was influenced by some porosity seen that was attributed to incomplete outgassing from the powder mix before HIPping.

Creep results are shown in Table 3 . The creep lives of all the samples are relatively poor. The best creep life belongs to 410 as-HIPped material, being $679 \mathrm{~h}$ under $75 \mathrm{MPa}$ load at $625^{\circ} \mathrm{C}$. The worst creep life is for the ODS-50-nm sample, again owing to the porosity present.

Larsson Miller parameters (LMP) have been calculated from the results obtained in mini-creep tests and are shown in Fig. 4.

\subsection{Microstructural Characteristics and Fractography}

All four materials show similar microstructure after heat treatment. They all have tempered martensite as expected. A significant feature observed in the microstructure was inclusion 


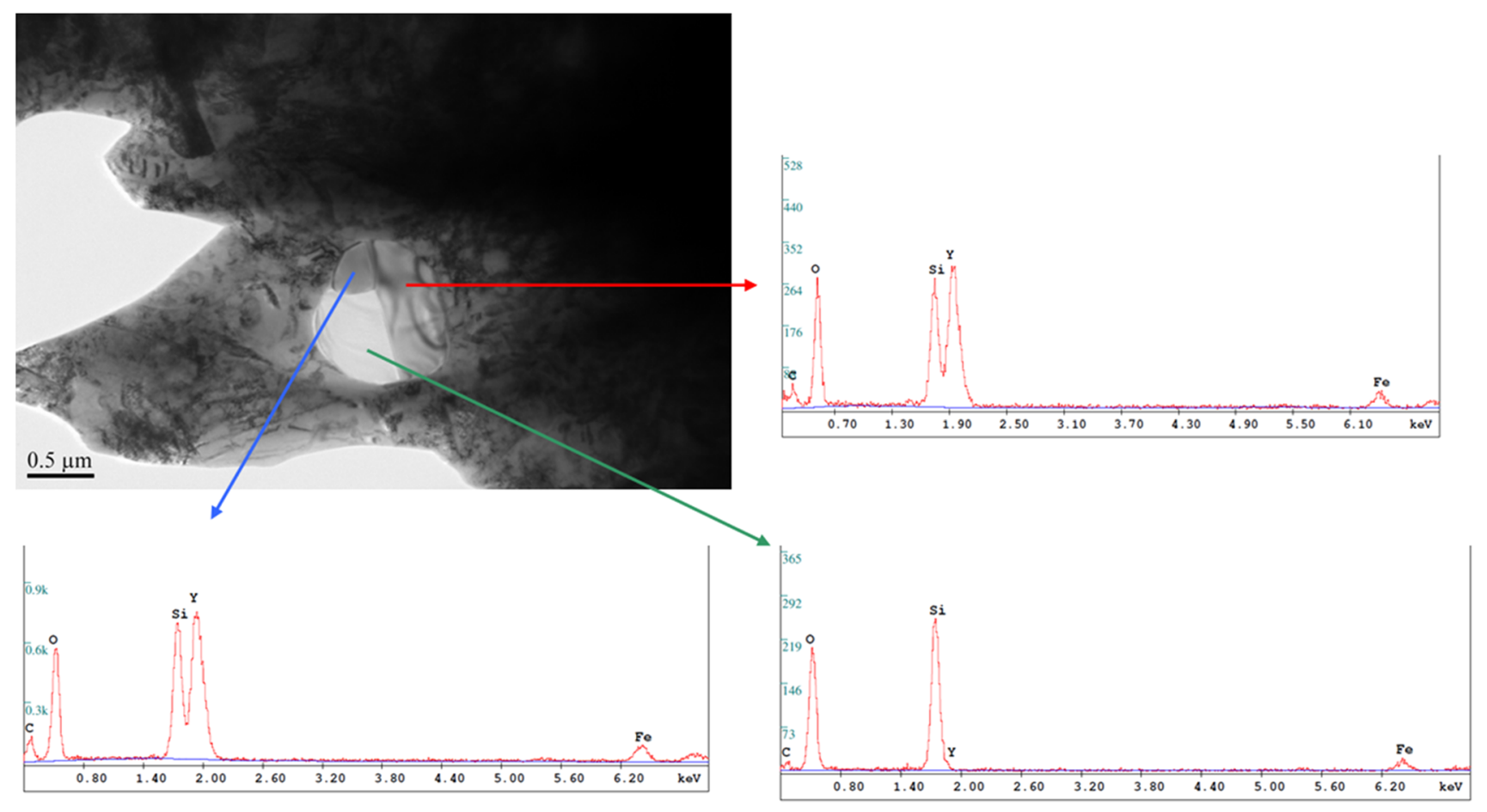

Fig. 7 TEM image and EDX result of one of the intermetallic particles in ODS with 50-nm $\mathrm{Y}_{2} \mathrm{O}_{3}$

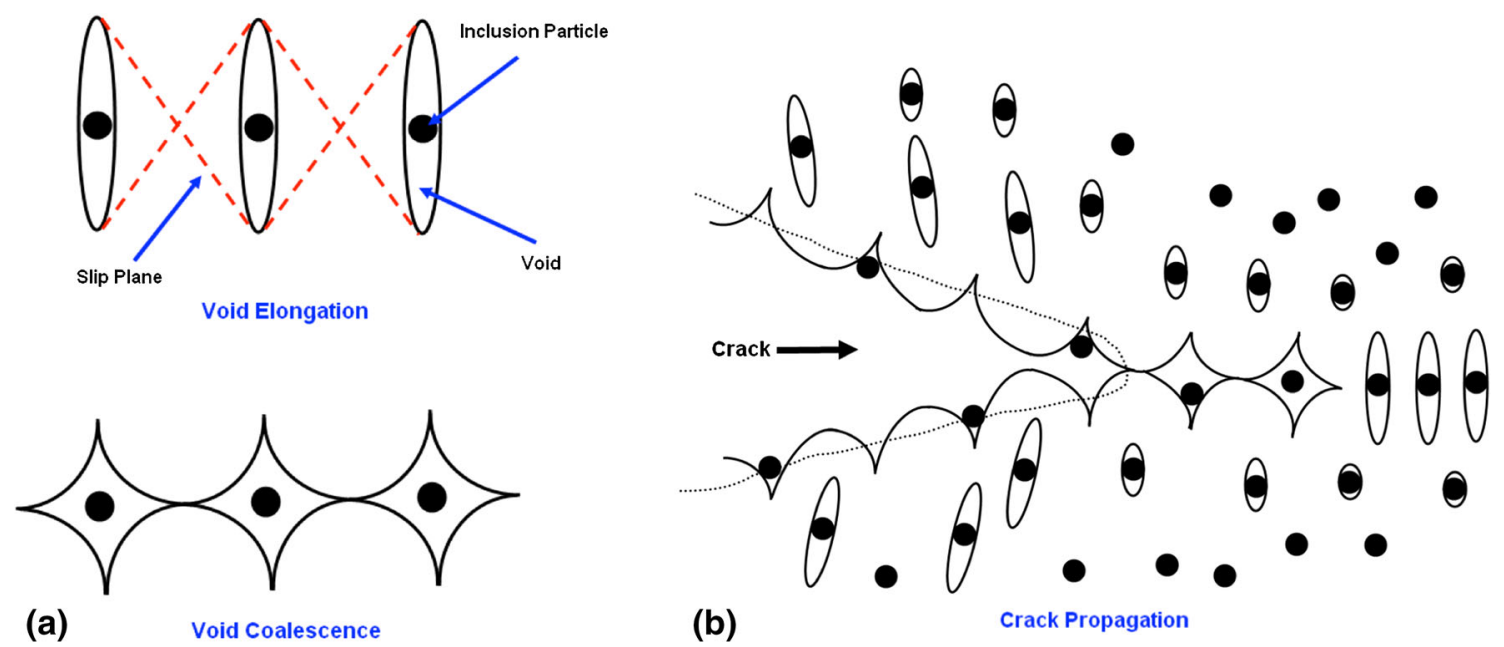

Fig. 8 Schematic illustration of (a) void elongation and coalescence (b) crack propagation

particles, or particle clusters. They can be seen both in metallography samples and on the fracture surfaces after tensile tests, as shown in Fig. 5. They are seen in both MA and nonMA materials, with and without dispersed yttria. EDX analysis showed that these inclusions are rich in silicon-oxygen and manganese-sulfur in non-ODS materials. In the ODS materials, some silicon-oxygen-yttrium particles were also detected. Some of the particles were a combination of two or more different particles as can be seen in Fig. 5b, with compositional differences shown using energy-dispersive $\mathrm{x}$-ray diffraction, in the SEM, in Fig. 6.

The reason for seeing the association of $\mathrm{Si}$ and $\mathrm{O}$ is due to the fact that silicon is the most common oxidizing agent in steel. Oxygen is considered as an undesirable element, causing reduction in mechanical properties by oxides and inclusions. So, $\mathrm{SiO}_{2}$ particles are formed due to interaction between $\mathrm{Si}$ and $\mathrm{O}$. MnS particles are formed on similar lines. Manganese is a good desulfurizer; it is employed on alloying to form the stable $\mathrm{MnS}$ phase so that it eliminates hot-shortness or sulfur embrittlement. In ODS samples, due to the interaction between silicon and oxygen in the yttria particles, we observed Y-, Si-, and $\mathrm{O}$-containing clusters as a particle comprising on one side an Si-O part and Y-Si-O on the other side, as can be seen from the TEM image in Fig. 7.

The 410L was supplied in pre-alloyed form. Formations of the $\mathrm{SiO}_{2}$ and $\mathrm{MnS}$ particles will have occurred during the liquid stage of the steel fabrication as a result of supersaturation of the solution with the solutes due to dissolution of additives 
(deoxidation and desulfurization agents). So, this would suggest that these particles were in the system before the ball milling stage. These inclusions were observed in 410L HIPed material (without MA). However, the interaction between Si-O$\mathrm{Y}$ will have started during the milling stage, because MA is the first step where yttria is added to the system. These facts can be used to infer that a nucleation and growth process occurred. During milling, some $\mathrm{SiO}_{2}$ particles interacted with yttria particles due to the high energy of the milling process and formed a new composition of Y-Si-O. In addition, during the high-temperature HIP process, those particles or clusters joined and grew together, forming a minimum energy shape, most of the time spherical. These clusters' size could also have been enhanced by the subsequent heat treatment.

\section{Discussion}

The PM and HIP process used here for the 410L martensitic stainless steels increased the material strength as compared to

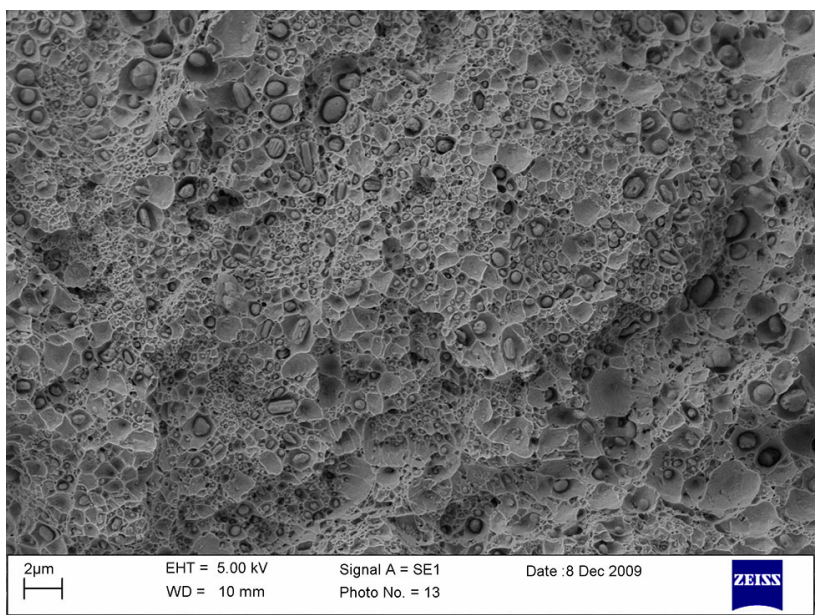

Fig. 9 Creep fracture surface from the ODS material with 50-nm yttria particles conventional processing. The ODS materials, however, did not show improved mechanical properties at room temperature. They have nearly the same mechanical properties than the nonODS materials, yet they showed a lower fracture strain.

Ductility in these materials is controlled by microvoid nucleation and coalescence prior to fracture (Ref 24). Propagation of a fracture is the combination of nucleation of voids and growth and/or coalescence of these voids owing to plastic strain. One of the most important factors in the nucleation of voids is the interfacial bonds. As the inclusions in the materials tend to have very low-strength interface bonds, they are potential void nucleation points. Some inclusions like MnS can also be considered as virtual voids, i.e., with very little or no bond to the matrix surrounding them. In the case of oxides, void nucleation starts by particle cracking; while for sulfides, which have a lower interfacial energy between inclusion and the matrix, decohesion occurs at the inclusion/matrix interface, even at low strains.

After voids are nucleated at the inclusions owing to weak interfacial bonds, they tend to elongate along the tensile direction up to a certain limit by plastic extension. This limit is defined as the distance between neighbor inclusions. When they reach that limit, a slip plane is formed between voids, and they coalesce (Ref 25). This continues through all neighboring inclusions, and then, fracture propagates leading to complete rupture. The fractography analyses show inclusions inside the dimples where the microvoid nucleation has started. Figure 8 shows the mechanism of void elongation and coalescence under plastic extension followed by crack propagation and matrix separation leading to fracture (Ref 26). Thus, if the distance between these inclusions is small, the plastic strain needed to coalesce the nucleated voids will be less as well, which means the total fracture strain will be smaller and in consequence, the material has low ductility.

During creep, voids and cracks nucleate at grain boundaries and follow grain boundaries until rupture. The low creep lives observed are associated with the inclusion particles present at grain boundaries which ease the nucleation and propagation. Inclusion particles were clearly observed on the fracture surfaces following creep testing, as seen in Fig. 9. There was a high density of particles observed on the creep fracture surfaces. It was clear that the particles had initiated multiple
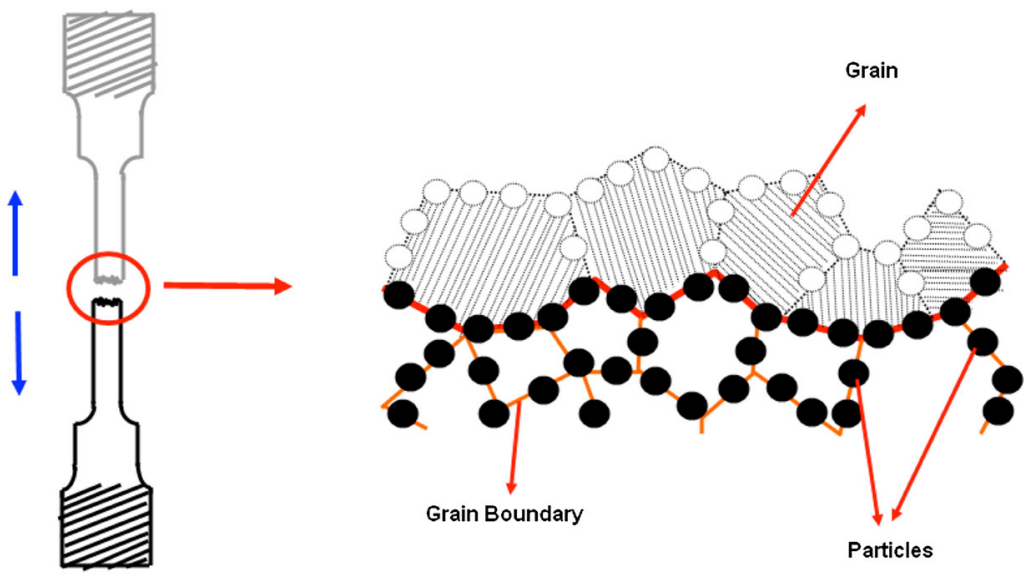

Tensile Test Specimen After Fracture

Fig. 10 Illustration of crack propagation during tensile test showing inclusion density difference between fractography and metallography samples 

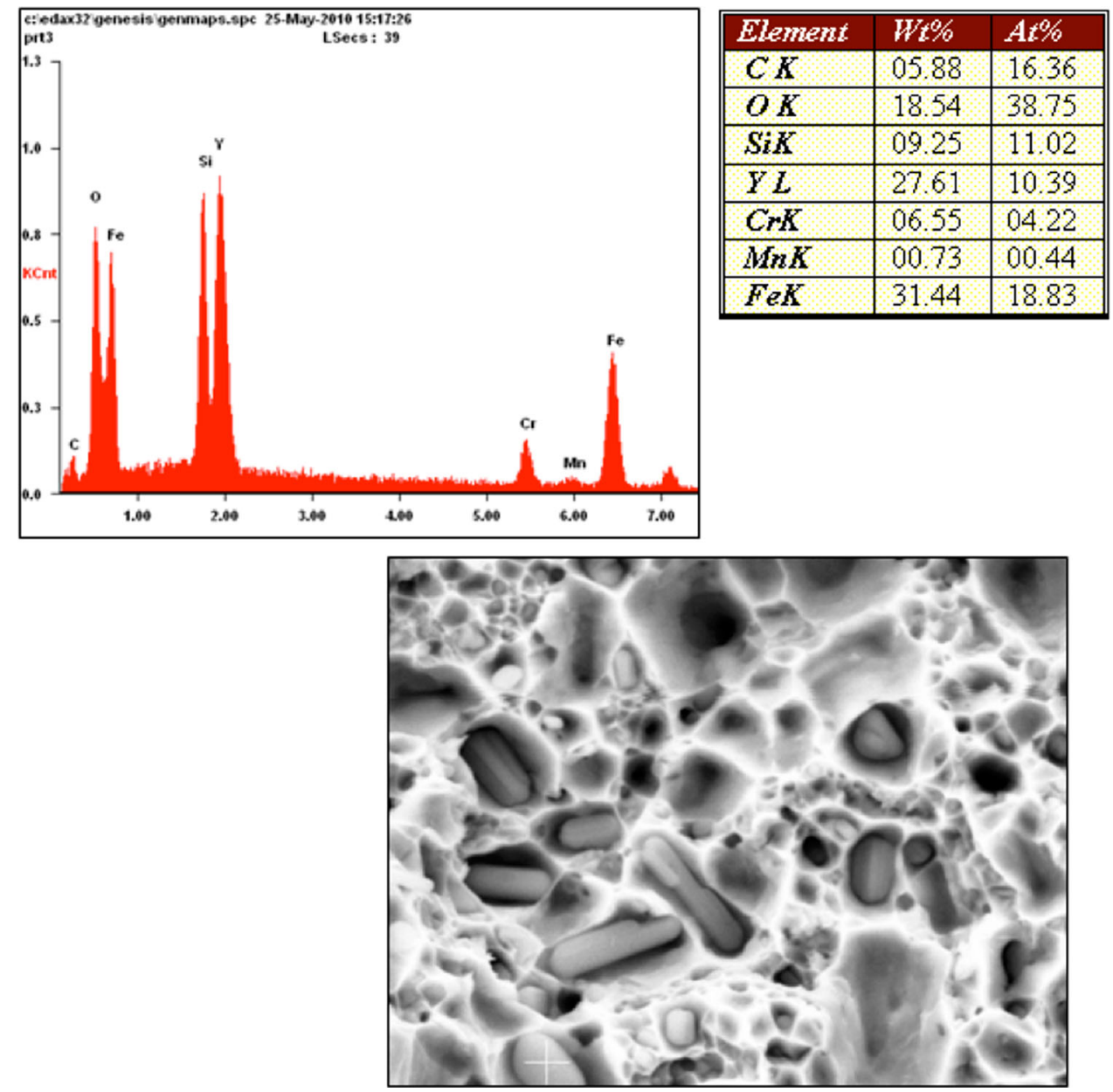

Fig. 11 EDX results showing $\mathrm{Y}-\mathrm{Si}-\mathrm{O}$ particles are $\mathrm{Y}_{2} \mathrm{Si}_{2} \mathrm{O}_{7}$

voiding within the material and that this had led to an early onset of tertiary creep and a concomitantly low creep life.

Some of the particles are composed of two or more individual particles. Figure 10 indicates schematically why there are more particles seen on the fracture surface SEM image than are present as a volume fraction in the material.

Particles were observed in both non-ODS and ODS variants of the materials. In the non-ODS material, the particles are comprised of $\mathrm{MnS}$ and $\mathrm{Si}-\mathrm{O}$ systems. In the ODS material, $\mathrm{Si}-\mathrm{O}, \mathrm{Y}-\mathrm{Si}-\mathrm{O}$, and $\mathrm{MnS}$ were seen to form particle clusters.

The Y-Si-O particles are expected to be $\mathrm{Y}_{2} \mathrm{Si}_{2} \mathrm{O}_{7}$ which is thermodynamically favorable (Ref 27). Figure 11 shows EDX data taken from the fracture surface of an ODS-0.9- $\mu \mathrm{m}$ sample after room temperature tensile testing. These EDX results show that the atom percentages of $\mathrm{Y}, \mathrm{Si}$, and $\mathrm{O}$ satisfy the condition of $\mathrm{Y}_{2} \mathrm{Si}_{2} \mathrm{O}_{7}$ as 1 atom for each $\mathrm{Y}$ and $\mathrm{Si}$ and 3.5 atoms for $\mathrm{O}$. Similar atomic calculations show that the other particles are $\mathrm{SiO}_{2}$ and $\mathrm{MnS}$ particles.

Agglomeration of the inclusions, resulting in a much bigger overall particle size, has a negative effect when compared to particles of smaller sizes. Such larger particles tend to form voids at lower strains than smaller particles, which impairs rather than improves the mechanical properties.

There is an important point about the Y-Si-O interaction and formation of $\mathrm{Y}_{2} \mathrm{Si}_{2} \mathrm{O}_{7}$ particles. It is quite common that yttria particles dissolve in the matrix during ball milling and precipitate again as pure yttria in the system at high temperature later in the manufacturing process: this is the main mechanism to disperse the matrix with oxide particles to make oxidedispersion-strengthened alloys. This dissolution and precipitation are needed for a homogeneous microstructure and size control of oxide dispersions in the nanometre range (Ref 28). If yttria dissolved in the matrix and then precipitated, then there should be separate particles with composition $\mathrm{Y}_{2} \mathrm{O}_{3}$ or complex oxides such as $\mathrm{Y}_{2} \mathrm{Ti}_{2} \mathrm{O}_{7}$ if $\mathrm{Ti}$ was added to the system. In our case, the yttria-containing particles studied by SEM and EDX analysis are all $\mathrm{Y}_{2} \mathrm{Si}_{2} \mathrm{O}_{7}$. However, small-angle neutron scattering (SANS) experiment results showed that there are pure $\mathrm{Y}_{2} \mathrm{O}_{3}$ oxide particles in the system at the nanometre level which cannot be detected in the SEM. SANS results from a pore-free batch of the ODS-50-nm material are shown in Fig. 12. The size of the $\mathrm{Y}_{2} \mathrm{O}_{3}$ particles in the as-received condition was measured as $33 \mathrm{~nm}$. So, in the system, there are both $\mathrm{Y}_{2} \mathrm{O}_{3}$ and $\mathrm{Y}_{2} \mathrm{Si}_{2} \mathrm{O}_{7}$ particles together.

In the literature, it is reported that up to $15 \mathrm{wt} \%$ yttria has been dissolved in ball milling in Fe-24 wt.\% Cr steel (Ref 29). Since the material being investigated contains $0.25 \mathrm{wt} . \%$ yttria, it can be assumed that it is highly likely that yttria could be fully dissolved. On the other hand, some research on ODS manufacturing shows that yttria does not "dissolve" during ball milling, rather the effect is a reduction in size to a few nanometres due to fracturing or amorphization of the yttria 

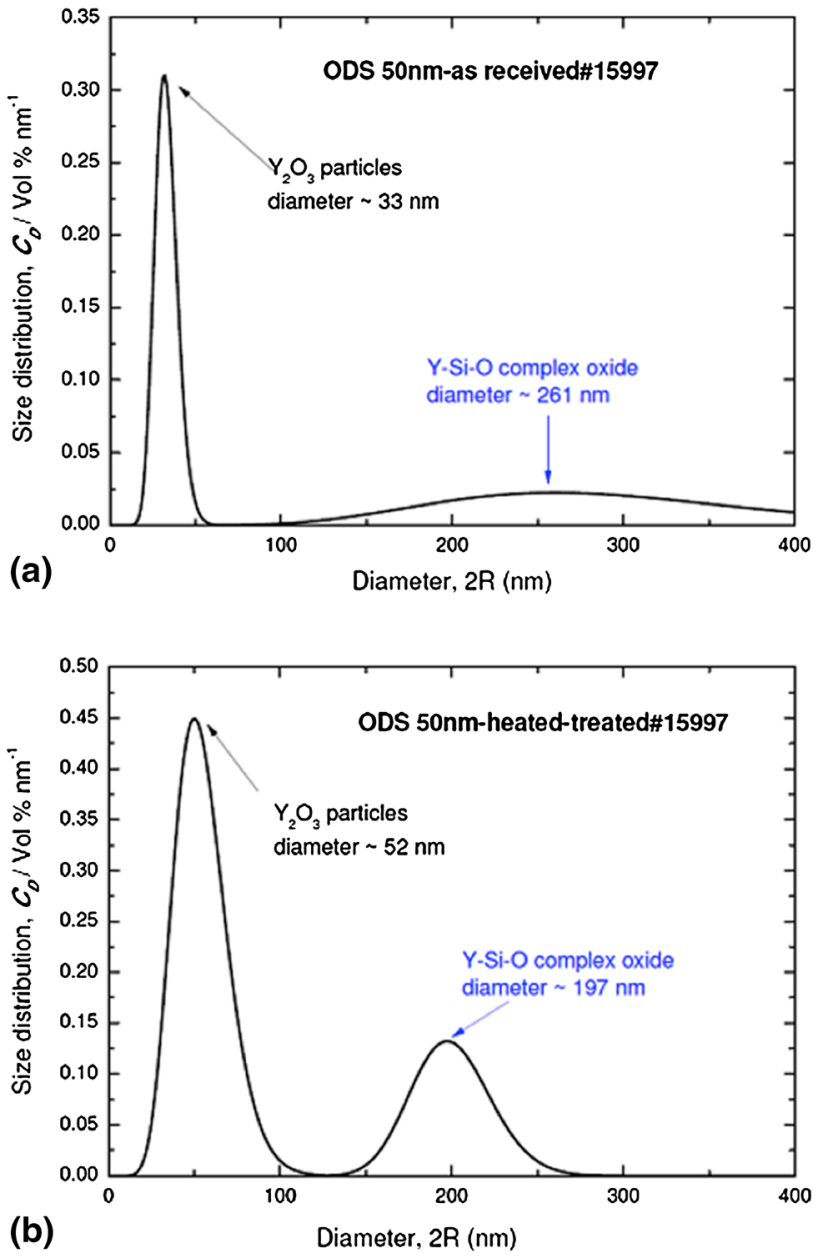

Fig. 12 SANS data from ODS $50 \mathrm{~nm}$ in the (a) as-received (b) heat-treated condition

which takes place at the interfaces of the matrix (Ref 18, 30). In many ODS analyses, the size of the oxide clusters was found to be around 1-4 $\mathrm{nm}$ after dissolution and precipitation (Ref 3135). Even after heat treatment and coarsening of the particles, oxide clusters of size around $10 \mathrm{~nm}$ are observed (Ref 35). So, it is not likely that oxide particles of $33 \mathrm{~nm}$ are formed by dissolution and precipitation mechanisms, because even initially, the yttria particles were reported as $50 \mathrm{~nm}$. It is more likely that the formations of oxide clusters seen here are a result of interaction between the yttria and $\mathrm{SiO}_{2}$ particles during ball milling. The pure $\mathrm{Y}_{2} \mathrm{O}_{3}$ particles $(33 \mathrm{~nm})$ detected by SANS can be attributed to size reduction of the particles owing to fracturing in the MA process. The size of the yttria particles should decrease to some extent for dissolution to occur, as in theory $\mathrm{Y}$ and $\mathrm{O}$ are thought to enter the matrix lattice.

The presence of $\mathrm{SiO}_{2}$ will, therefore, have a significant effect on the microstructure of ODS steels by preventing dissolution of the yttria and/or leading to nucleation (if there is dissolution and precipitation) of complex $\mathrm{Y}_{2} \mathrm{Si}_{2} \mathrm{O}_{7}$ oxides. This complex oxide should not be mistaken with $\mathrm{Y}_{2} \mathrm{Ti}_{2} \mathrm{O}_{7}$ or $\mathrm{Y}_{2} \mathrm{TiO}_{5}$ which are known to be better in strengthening ODS systems, as $\mathrm{Ti}$ is added to ODS systems purposely to improve mechanical performance. The sizes of the complex $\mathrm{Y}_{2} \mathrm{Si}_{2} \mathrm{O}_{7}$ particles are relatively large due to their formation from the relatively large $\mathrm{SiO}_{2}$ inclusions, with the size of the particles reaching 2- $\mu \mathrm{m}$
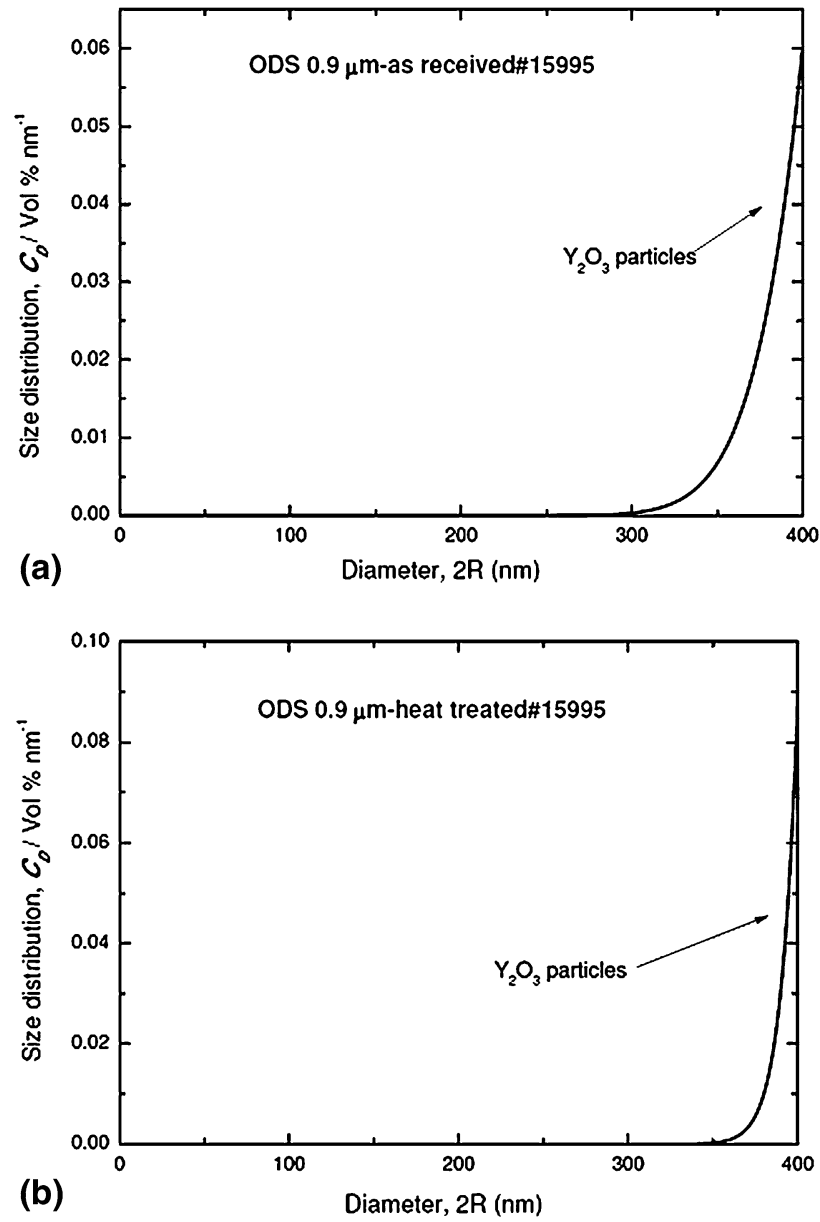

Fig. 13 SANS data from ODS $0.9 \mu \mathrm{m}$ in the (a) as-received (b) heat-treated condition

level in some cases, which is clearly not desirable. It has previously been observed that yttria particles in ODS steels have an affinity for Si (Ref 36).

As shown in Fig. 12, the size of the particles changed with heat treatment. The mean size of the $\mathrm{Y}_{2} \mathrm{O}_{3}$ increased from 33 to $52 \mathrm{~nm}$ after heat treatment, whereas the mean size of the complex oxide $\mathrm{Y}_{2} \mathrm{Si}_{2} \mathrm{O}_{7}$ decreased from 261 to $197 \mathrm{~nm}$. It is expected to have larger clusters after heat treatment as particles coarsen at high temperatures. However, the size of the complex oxide decreased. It can also be seen that the peak of pure yttria $\left(\mathrm{Y}_{2} \mathrm{O}_{3}\right)$ broadened and the peak of the complex oxide (Y-Si-O) became narrower after heat treatment. The results also suggest that larger complex oxide particles dissolved prior to small ones because it is shown that minimum size of the complex particles increased in heat-treated condition from around 100 to $150 \mathrm{~nm}$ but the average size together with the maximum size decreased. So, this can be attributed to preferential dissolution of larger particles.

SANS results from the ODS $0.9 \mu \mathrm{m}$ are shown in Fig. 13. As the maximum size of the particles that can be measured by the available SANS instrument was limited to $400 \mathrm{~nm}$, only the start of the size distribution graph of $\mathrm{Y}_{2} \mathrm{O}_{3}$ particles is obtained. However, when compared to heat-treated and as-received results, it can be noted that the minimum size of the $\mathrm{Y}_{2} \mathrm{O}_{3}$ particles increases with heat treatment. Complex particles in this case are much larger than $400 \mathrm{~nm}$; so, these are not shown 
in the results. An important outcome of the SANS experiment on ODS $0.9 \mu \mathrm{m}$ is the effect of the initial yttria size on the size of the oxide particles after manufacturing. SANS results showed that the average size of the pure $\mathrm{Y}_{2} \mathrm{O}_{3}$ particles in ODS $0.9 \mu \mathrm{m}$ is greater than $400 \mathrm{~nm}$ in both as-received and heat-treated conditions. This can contribute to the conclusion that dissolution of the yttria in ball milling did not occur, because if the yttria was dissolved in the matrix, then after precipitation during compaction nanometer-sized yttria particles would be observed (Ref 37). It appears that yttria particles fractured into smaller pieces in the ball milling and some of those particles interacted with $\mathrm{SiO}_{2}$ and formed complex oxides and the remaining ones stayed as pure $\mathrm{Y}_{2} \mathrm{O}_{3}$ particles

\section{Conclusions}

1. ODS materials based on a $410 \mathrm{~L}$ steel matrix have been fabricated using a mechanical alloying, powder metallurgy route. All the materials presented an increase in strength when compared to conventional material of the same composition. However, yttria additions did not significantly alter the properties.

2. Complex compound particles of yttria combined with sulfide or oxide inclusions were seen on the metallographic samples and fracture surfaces of the various materials studied.

3. From SANS results, it is concluded that the yttria did not dissolve during the ball milling process. The yttria particles interacted with $\mathrm{SiO}_{2}$ inclusions to form $\mathrm{Y}_{2} \mathrm{Si}_{2} \mathrm{O}_{7}$. During heat treatment, the complex $\mathrm{Y}_{2} \mathrm{Si}_{2} \mathrm{O}_{7}$ particles begin to disassociate, which causes a size reduction for the complex oxide and a size increase for pure yttria particles.

4. Mini-creep testing was undertaken on the materials, and the creep properties were found to be significantly impaired relative to what is expected for the material at the temperatures tested. This is attributed to the particle clusters causing high local deformation rates leading to relatively early failure.

\section{Acknowledgment}

This project was supported by the RCUK Energy Programme, and we are grateful to EPSRC for funding via the PROMINENT Nuclear Fission consortium grant. The authors would like to thank JCNS for SANS beam time, also Dr A. Feoktystov for the technical assistance. MEF is grateful for funding from the Lloyd's Register Foundation, a charitable foundation helping to protect life and property by supporting engineering-related education, public engagement, and the application of research. The contribution from Prof. Mehmet Turker, Head of Turkish Powder Metallurgy Association and Professor in Gazi University, is gratefully acknowledged.

\section{Open Access}

This article is distributed under the terms of the Creative Commons Attribution License which permits any use, distribution, and reproduction in any medium, provided the original author(s) and the source are credited.

\section{References}

1. A. Kohyama, A. Hishinuma, D.S. Gelles, R.L. Klueh, W. Dietz, and K. Ehrlich, Low-Activation Ferritic and Martensitic Steels for Fusion Application, J. Nucl. Mater., 1996, 233-237(1), p 138-147

2. I.A. Shibli and D.G. Robertson, Review of the Use of New High Strength Steels in Conventional and HRSG Boilers: R\&D and Plant Experience, European Technology Development Ltd, UK, 2006

3. M. Morakotjinda, N. Kuljittipipat, N. Poolthong, N. Tosangthum, P. Wila, R. Krataitong, T. Yodkaew, O. Coovattanachai, B. Vetayanugul, and R. Tongsri, Sintered Materials Prepared from Stainless Steel Series 300 and 400 Powders, J. Met. Mater. Miner., 2008, 18(1), p 69-74

4. R. Klueh and D.R. Harries, High Chromium Ferritic and Martensitic Steels for Nuclear Applications, ASTM, 2001

5. P. Dubuisson, Y. de Carlan, V. Garat, and M. Blat, ODS Ferritic/ Martensitic Alloys for Sodium Fast Reactor Fuel Pin Cladding, J. Nucl. Mater, 2012, 428(1-3), p 6-12

6. M.B. Toloczko, D.S. Gelles, F.A. Garner, R.J. Kurtz, and K. Abe, Irradiation Creep and Swelling from 400 to $600{ }^{\circ} \mathrm{C}$ of the Oxide Dispersion Strengthened Ferritic Alloy MA957, J. Nucl. Mater, 2004, 329-333, p 352-355

7. H. Kishimoto, K. Yutani, R. Kasada, O. Hashitomi, and A. Kimura, Heavy-Ion Irradiation Effects on the Morphology of Complex Oxide Particles in Oxide Dispersion Strengthened Ferritic Steels, J. Nucl. Mater., 2007, 367-370, p 179-184

8. Z. Oksiuta, M. Lewandowska, and K.J. Kurzydłowski, Mechanical Properties and Thermal Stability of Nanostructured ODS RAF Steels, Mech. Mater., 2013, 67, p 15-24

9. L. Fave, M.A. Pouchon, M. Döbeli, M. Schulte-Borchers, and A. Kimura, Helium Ion Irradiation Induced Swelling and Hardening in Commercial and Experimental ODS Steels, J. Nucl. Mater., 2014, 445(1-3), p 235-240

10. M.C. Brandes, L. Kovarik, M.K. Miller, G.S. Daehn, and M.J. Mills, Creep Behavior and Deformation Mechanisms in a Nanocluster Strengthened Ferritic Steel, Acta Mater, 2012, 60(4), p 1827-1839

11. M. Ratti, D. Leuvrey, M.H. Mathon, and Y. de Carlan, Influence of Titanium on Nano-Cluster (Y, Ti, O) Stability in ODS Ferritic Materials, J. Nucl. Mater, 2009, 386-388, p 540-543

12. H. Hadraba, B. Fournier, L. Stratil, J. Malaplate, A.L. Rouffié, P. Wident, L. Ziolek, and J.L. Béchade, Influence of Microstructure on Impact Properties of 9-18\%Cr ODS Steels for Fusion/Fission Applications, J. Nucl. Mater., 2011, 411(1-3), p 112-118

13. M. Tamura, H. Sakasegawa, A. Kohyama, H. Esaka, and K. Shinozuka, Creep Deformation of Iron Strengthened by MX Type Particles, J. Nucl. Mater., 2004, 329-333, p 328-332

14. R.L. Klueh, P.J. Maziasz, I.S. Kim, L. Heatherly, D.T. Hoelzer, N. Hashimoto, E.A. Kenik, and K. Miyahara, Tensile and Creep Properties of an Oxide Dispersion-Strengthened Ferritic Steel, J. Nucl. Mater, 2002, 307-311, p 773-777

15. A. Alamo, V. Lambard, X. Averty, and M.H. Mathon, Assessment of ODS-14\%Cr Ferritic Alloy for High Temperature Applications, J. Nucl. Mater, 2004, 329-333, p 333-337

16. I. Kubena and T. Kruml, Fatigue Life and Microstructure of ODS Steels, Eng. Fract. Mech., 2013, 103, p 39-47

17. M.H. Mathon, M. Perrut, S.Y. Zhong, and Y. de Carlan, Small Angle Neutron Scattering Study of Martensitic/Ferritic ODS Alloys, J. Nucl. Mater, 2012, 428(1-3), p 147-153

18. L. Toualbi, M. Ratti, G. André, F. Onimus, and Y. de Carlan, Use of Neutron and $\mathrm{x}$-Ray Diffraction to Study the Precipitation Mechanisms of Oxides in ODS Materials, J. Nucl. Mater., 2011, 417(1-3), p 225-228

19. H. Zhang, M.J. Gorley, K.B. Chong, M.E. Fitzpatrick, S.G. Roberts, and P.S. Grant, An In-Situ Powder Neutron Diffraction Study of NanoPrecipitate Formation During Processing of Oxide-DispersionStrengthened Ferritic Steels, J. Alloys Compd., 2014, 582, p 769-773

20. R.M. German, Powder Metallurgy and Particulate Materials Processing, Metal Powder Industries Federation, New Jersey, 2005

21. J.A. Silas and E.W. Kaler, Effect of Multiple Scattering on SANS Spectra from Bicontinuous Microemulsions, J. Colloid Interface Sci., 2003, 257(2), p 291-298

22. Z. Brytan, L.A. Dobrzański, M.A. Grande, and M. Rosso, Characteristic of Vacuum Sintered Stainless Steels, J. Achiev. Mater. Manuf. Eng., 2009, 33(2), p 126-134

23. V. de Castro, T. Leguey, A. Muñoz, M.A. Monge, P. Fernández, A.M. Lancha, and R. Pareja, Mechanical and Microstructural Behaviour of 
$\mathrm{Y}_{2} \mathrm{O}_{3}$ ODS EUROFER 97, J. Nucl. Mater, 2007, 367-370(Part A), p 196-201

24. I. Sabirov and O. Kolednik, The Effect of Inclusion Size on the Local Conditions for Void Nucleation Near a Crack Tip in a Mild Steel, Scr. Mater, 2005, 53(12), p 1373-1378

25. L.M. Brown and J.D. Embury, The Initiation and Growth of Voids at Second Phase Particles. In 3rd International Conference on Strength of Metals and Alloys, Institution of Metals, London, 1973, p 164-169

26. R. Rungta, ed., Inclusions and Their Influence on Material Behavior, ASM International, 1988

27. T.K. Kim, C.S. Bae, D.H. Kim, J. Jang, S.H. Kim, C.B. Lee, and D. Hahn, Microstructural Observation and Tensile Isotropy of an Austenitic ODS Steel, Nucl. Eng. Technol., 2008, 40(4), p 305-310

28. D.-H. Liu, Y. Liu, D.-P. Zhao, Y. Wang, J.-H. Fang, Y.-R. Wen, and Z.-M. Liu, Effect of Ball Milling Time on Microstructures and Mechanical Properties of Mechanically-Alloyed Iron-Based Materials, Trans. Nonferr. Met. Soc. China, 2010, 20(5), p 831-838

29. Y. Kimura, S. Takaki, S. Suejima, R. Uemori, and H. Tamehiro, Ultra Grain Refining and Decomposition of Oxide During Super-heavy Deformation in Oxide Dispersion Ferritic Stainless Steel Powder, ISIJ. Int. (Iron Steel Inst. Jpn.), 1999, 39(2), p 176-182

30. L. Dai, Y. Liu, and Z. Dong, Size and Structure Evolution of Yttria in ODS Ferritic Alloy Powder During Mechanical Milling and Subsequent Annealing, Powder Technol., 2012, 217, p 281-287

31. A.A. Aleev, N.A. Iskandarov, M. Klimenkov, R. Lindau, A. Möslang, A.A. Nikitin, S.V. Rogozhkin, P. Vladimirov, and A.G. Zaluzhnyi,
Investigation of Oxide Particles in Unirradiated ODS Eurofer by Tomographic Atom Probe, J. Nucl. Mater, 2011, 409(2), p $65-71$

32. M. Brocq, B. Radiguet, S. Poissonnet, F. Cuvilly, P. Pareige, and F. Legendre, Nanoscale Characterization and Formation Mechanism of Nanoclusters in an ODS Steel Elaborated by Reactive-Inspired BallMilling and Annealing, J. Nucl. Mater, 2011, 409(2), p 80-85

33. C. Heintze, F. Bergner, A. Ulbricht, M. Hernández-Mayoral, U. Keiderling, R. Lindau, and T. Weissgärber, Microstructure of Oxide Dispersion Strengthened Eurofer and Iron-Chromium Alloys Investigated by Means of Small-Angle Neutron Scattering and Transmission Electron Microscopy, J. Nucl. Mater., 2011, 416(1-2), p 35-39

34. M.K. Miller, K.F. Russell, and D.T. Hoelzer, Characterization of Precipitates in MA/ODS Ferritic Alloys, J. Nucl. Mater, 2006, 351(1-3), p 261-268

35. M.K. Miller, D.T. Hoelzer, E.A. Kenik, and K.F. Russell, Nanometer Scale Precipitation in Ferritic MA/ODS Alloy MA957, J. Nucl. Mater., 2004, 329-333, p 338-341

36. C.A. Williams, E.A. Marquis, A. Cerezo, and G.D.W. Smith, Nanoscale Characterisation of ODS-Eurofer 97 Steel: An Atom-Probe Tomography Study, J. Nucl. Mater, 2010, 400(1), p 37-45

37. R. Coppola, M. Klimiankou, R. Lindau, R.P. May and M. Valli, SANS and TEM Study of Y2O3 Particle Distributions in OxideDispersion Strengthened EUROFER Martensitic Steel for Fusion Reactors. Phys. B Condens. Matter., 2004, 350(1-3, Supplement), E545-E548 